\title{
Karyotype differentiation and cytotaxonomic considerations in species of Serrasalmidae (Characiformes) from the Amazon basin
}

\author{
Celeste Mutuko Nakayama ${ }^{1}$, Eliana Feldberg ${ }^{1}$ and Luiz Antonio Carlos Bertollo ${ }^{2}$
}

\begin{abstract}
Six species of Serrasalmidae from the central Amazon, representatives of the genera Serrasalmus (S. elongatus, S. maculatus, S. cf. rhombeus, and S. rhombeus), Pygocentrus (P. nattereri), and Colossoma (C. macropomum), were analyzed regarding the distribution of the Ag-NORs, C-positive heterochromatin and 18S and 5S rRNAgenes on the chromosomes. All specimens had 2n $=60$ chromosomes, except $S$. cf. rhombeus, with $2 \mathrm{n}=58$, and $C$. macropomum with $2 \mathrm{n}=54$ chromosomes. The Ag-NORs were multiple and located on the short arms of subtelo-acrocentric chromosomes in all Serrasalmus species and in P. nattereri, but were found on metacentric chromosomes in C. macropomum. The $18 \mathrm{~S}$ rDNA sites were usually coincident with Ag-NORs, although some species had a higher number and/or a distinct localization of these sites. C-positive heterochromatin was preferentially situated in centromeric regions, remarkably on metacentric pair number 7 in all Serrasalmus species and number 3 in $P$. nattereri, which beared a conspicuous proximal C-band on the long arms. The $5 \mathrm{~S}$ rDNA sites were detected in a single chromosomal pair in all species. In Serrasalmus and P. nattereri, this pair was the number 7 and 3 , respectively, thereby revealing its co-localization with the conspicuous heterochromatic band. However, in C. macropomum, only one homologue (probably belonging to pair number 12) exhibited 5S rDNA sites on the short arms, close to the centromere. The present data revealed reliable cytotaxonomic markers, enabling the evaluation of karyotype differentiation and interrelationships among Serrasalmidae, as well as the probable occurrence of a species complex in $S$. rhombeus.
\end{abstract}

Seis espécies de Serrasalmidae da Amazônia central, representantes dos gêneros Serrasalmus (S. elongatus, S. maculatus, $S$. cf. rhombeus e $S$. rhombeus ), Pygocentrus (P. nattereri) e Colossoma (C. macropomum), foram analisadas quanto à distribuição das Ag-RONs, heterocromatina C-positiva e dos genes de RNAr $18 \mathrm{~S}$ e $5 \mathrm{~S}$ nos cromossomos. Todos os espécimes apresentaram $2 \mathrm{n}=60$ cromossomos, exceto $S$. cf. rhombeus, com $2 \mathrm{n}=58$, e C. macropomum com $2 \mathrm{n}=54$ cromossomos. As Ag-RONs foram múltiplas e localizadas nos braços curtos de cromossomos subtelo-acrocêntricos em todas as espécies de Serrasalmus e em $P$. nattereri, mas foram encontrados em cromossomos metacêntricos em C. macropomum. Os sítios de DNAr 18S, foram geralmente coincidentes com as Ag-RONs, embora algumas espécies tenham apresentado um maior número e/ou uma localização distinta desses sítios. A heterocromatina C-positiva foi preferencialmente encontrada como uma conspícua banda proximal no par metacêntrico número $7 \mathrm{em}$ todas as espécies de Serrasalmus e número $3 \mathrm{em} P$. nattereri. Os sítios de DNAr 5S foram detectados em um único par cromossômico nas seis espécies sendo que nas espécies de Serrasalmus, este par foi o de número 7 e em $P$. nattereri o de número 3 , colocalizados com bandas heterocromáticas conspícuas. No entanto, em C. macropomum, apenas um homólogo (provavelmente pertencente ao par número 12) apresentou sítios de DNAr $5 \mathrm{~S}$ nos braços curtos, próximos ao centrômero. Os dados apresentados revelaram confiáveis marcadores citotaxonômicos, permitindo a avaliação da diferenciação cariotípica, e as inter-relações entre Serrasalmidae, bem como a provável ocorrência de um complexo de espécies em $S$. rhombeus.

Key words: Chromosomal evolution, Fish, Heterochromatin, Piranhas, Ribosomal genes.

\section{Introduction}

Chromosome banding techniques have been useful in evolutionary cytogenetics, as they allow the identification of potential chromosome markers related to karyotype interrelationships. The detection of nucleolar organizer regions (NORs) by silver nitrate staining (Ag-NORs) has been one of the most widely employed procedures in fish, especially from 1980s on, providing important information for cytotaxonomic and evolutionary studies (Galetti Jr. et al., 1984; Gold, 1984;
Venere \& Galetti Jr., 1989; Feldberg et al., 1992, 2003). This tool is usually poorly informative for groups with single NORs on equivalent chromosomes. Moreover, not all the nucleolar organizer regions are necessarily active in species bearing multiple NOR systems and would therefore remain undetectable by silver nitrate staining (Miller et al., 1976).

Since the 1990s, chromosome studies have improved quickly due to the use of base-specific fluorochromes, such as chromomycin $\mathrm{A}_{3}$ and mithramycin, and the development of fluorescent in situ hybridization (FISH). These procedures have

\footnotetext{
${ }^{1}$ Instituto Nacional de Pesquisas da Amazônia (INPA), Coordenação de Pesquisas em Biologia Aquática, Laboratório de Genética de Peixes, Caixa Postal 478, 69011-970 Manaus, AM, Brazil. celnaka@inpa.gov.br(CMN)

${ }^{2}$ Universidade Federal de São Carlos, Departamento de Genética e Evolução, Caixa Postal 676, 13565-905 São Carlos, SP, Brazil.
} 
been successfully applied to NORs and heterochromatin studies in fish metaphase chromosomes, as they are able to detect base richness and both active and inactive nucleolar regions. Fluorescent in situ hybridization (FISH) is the most useful method for mapping NOR sites in a species genome.

The aim of the present study was to determine the location of 5S rDNA and 18S rDNA sites in species of Serrasalmidae from the central Amazon and carry out a comparative analysis with Ag-NORs. These data, along with other peculiar karyotype characteristics, proved to be important tools for understanding the interrelationships within this fish group.

\section{Material and Methods}

Six species of the family Serrasalmidae were analyzed: Serrasalmus elongatus Kner, 1858, S. maculatus Kner, 1858, S. rhombeus (Linnaeus, 1766), S. cf. rhombeus, Pygocentrus nattereri Kner, 1858, and Colossoma macropomum (Cuvier, 1816) (Fig. 1). The specimens were collected from the central Amazon at Catalão Lake (0310'45"S 5954'25.4”W), Marchantaria island ( $\left.3^{\circ} 11^{\prime} 9.80^{\prime \prime} \mathrm{S} 59^{\circ} 51^{\prime} 42.41^{\prime \prime} \mathrm{W}\right)$, Anavilhanas (2 ${ }^{\circ} 38^{\prime} 58.17^{\prime}$ 'S 6047'58.97'W) and Uatumã River (01 ${ }^{\circ} 55^{\prime}$ 'S $59^{\circ} 28^{\prime} \mathrm{W}$ ) in Brazil, identified by Jansen Zuanon (INPA). Voucher specimens were deposited in the fish collection at the Instituto Nacional de Pesquisas da Amazônia (INPA) (S. elongatus: INPA 32907 and 32908; S. maculatus: INPA 32909 and 32910; S. rhombeus: INPA 32911 and 32912. S. cf. rhombeus: INPA 32913 and 32914; Pygocentrus nattereri: INPA 32916 and 32917; Colossoma macropomum: INPA 32906 and 32907).

The chromosome preparations were obtained from kidney cells, using the in vivo procedure described by Bertollo et al. (1978), after mitotic stimulation with biological yeast, using the procedure described by Oliveira et al. (1988). The chromosomes were classified as metacentric $(\mathrm{m})$, submetacentric $(\mathrm{sm})$, subtelocentric (st), and acrocentric (a) based on the arm ratio (Levan et al., 1964) and arranged in decreasing size in the karyotype. The fundamental number $(\mathrm{FN})$ or number of chromosomal arms was determined taking into account that $\mathrm{m}$, sm and st chromosomes bear two chromosomal arms and acrocentric chromosomes bear a single arm.

Constitutive heterochromatin (C-bands) was detected based on the procedure described by Sumner (1972). The nucleolar organizer regions were identified using silver nitrate staining (Ag-NORs), as proposed by Howell \& Black (1980), as well as fluorescent in situ hybridization (FISH), based on the procedure described by Pinkel et al. (1986). The $18 \mathrm{~S}$ rDNA probe was obtained through polymerase chain reaction (PCR) from the fish Prochilodus argenteus (Hatanaka \& Galetti Jr., 2004), using the primers NS1 (5'-GTAGTCATATGCTTGTCTC-3') and NS8 (5'-TCCGCAGGTTCACCTACGGA-3'), based on the procedure described by White et al. (1990). The 5S rDNA sites were detected using PCR-derived probes from the fish Leporinus obtusidens (Martins \& Galetti Jr., 1999), using the primers A(5'TACGCCCGATCTCGTCCGATC-3') and B (5'CAGGCTGGTATGGCCGTAAGC-3'), as reported by Pendás et al. (1994). Both probes were labeled by nick translation (BioNick

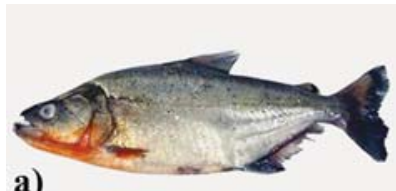

a)
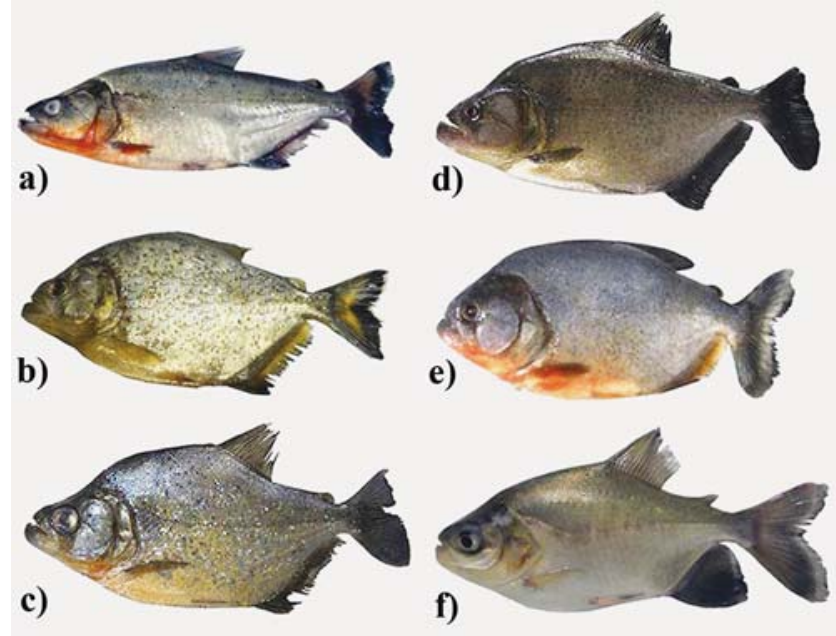

Fig. 1. Analyzed Serrasalmidae species: a) Serrasalmus elongatus (total length $=19.5 \mathrm{~cm}$ ); b) Serrasalmus maculatus (total length $=15.5 \mathrm{~cm}$ ); c) Serrasalmus cf. rhombeus (total length $=12.5 \mathrm{~cm})$; d) Serrasalmus rhombeus (total length $=$ $17.5 \mathrm{~cm}$ ); e) Pygocentrus nattereri (total length $=15.0 \mathrm{~cm}) ; \mathbf{f}$ ) Colossoma macropomum (total length $=19.0 \mathrm{~cm}$ ).

Labeling System - Invitrogen), following the manufacturer's instructions. The chromosomes were counter-stained with propidium iodide $(50 \mu \mathrm{g} / \mathrm{ml}$ and $200 \mu \mathrm{l}$ of antifading) and analyzed under an Olympus BX50 epifluorescence microscope. The images were digitized using the CoolSNAP-pro software program (Media Cybernetics).

\section{Results}

A diploid number of 60 chromosomes was found in all species, except $S$. cf. rhombeus, which had $2 \mathrm{n}=58$ chromosomes, and C. macropomum, which had $2 \mathrm{n}=54$ chromosomes. The fundamental number ranged from 106 to 110 and no sex-related chromosomes were found (Table 1).

All species exhibited multiple Ag-NORs, located in the terminal position on the short arms of acrocentric and subtelocentric chromosomes, with the exception of $C$. macropomum, in which the Ag-NORs were found on metacentric chromosomes (Fig. 2 a, c, e, g, i, and k). In general, the $18 \mathrm{~S}$ rDNA sites coincided with Ag-NOR sites. However, in some species, a higher number of $18 \mathrm{~S}$ rDNA sites were detected (Fig. 2 b, d, f, h, j, and 1).

Besides the general location of the C-bands in the centromeric regions (data not shown), a conspicuous heterochromatic block was also evident on the long arms of a metacentric pair close to the centromeres, corresponding to pair number 7 in the species of Serrasalmus and to pair number 3 in P. nattereri (Fig. 3 a, c, e, g, and i).

The 5S rDNA was located interstitially, close to the centromeres on a single chromosome pair. In Serrasalmus and Pygocentrus, this site was co-located with the aforementioned interstitial heterochromatic region on the long arms of pairs 7 and 3, respectively. In C. macropomum, 5S rDNA signals were 
found on the short arms of a single chromosome - probably from pair number 12 (Fig. 3 b, d, f, h, j, and l).

The results are summarized in Table 1. Previous data on another three species of Serrasalmus $[S$. altispinnis, $S$. gouldingi, and S. serrulatus (Nakayama et al., 2008)] were also included in this table to provide a comparative analysis.

\section{Discussion}

Ag-NORs in Serrasalmidae have been analyzed since the 1980s and have invariably been visualized as multiple sites usually located in the terminal region on the short arms of subtelo-acrocentric chromosomes, although some species bear terminal Ag-NORs on the long arms (Galetti Jr. et al., 1985; Almeida-Toledo et al., 1987; Cestari \& Galetti Jr. 1992a, b; Martins-Santos et al., 1994; Nakayama et al., 2001, 2002; 2008; Centofante et al., 2002a; Nirchio et al., 2003; Gaviria et $a l ., 2005)$. However, the numerical variation in these regions (in both inter and intra-specific terms) is much more notable than the positional differences, ranging from four sites in $C$. macropomum to 12 sites in S. rhombeus (Table 1).

This Ag-NOR variability is also supported by the FISH analysis of $18 \mathrm{~S}$ rDNA sites, indicating that, alongside with differences in diploid number, fundamental number and karyotype formula, Serrasalmidae species have undergone significant modifications in the chromosomal distribution of ribosomal genes during their evolutionary process. However, full correspondence between $18 \mathrm{~S}$ rDNA and Ag-NOR sites was not constantly observed, since in some species, the number of $18 \mathrm{~S}$ rDNA sites was greater than the number of Ag-NORs. Moreover, the location of some 18S rDNA sites was not detected by silver nitrate in $S$. rhombeus and $S$. serrulatus (Nakayama et al., 2008) (Table 1). Two probable reasons may putatively explain these divergences. Firstly,

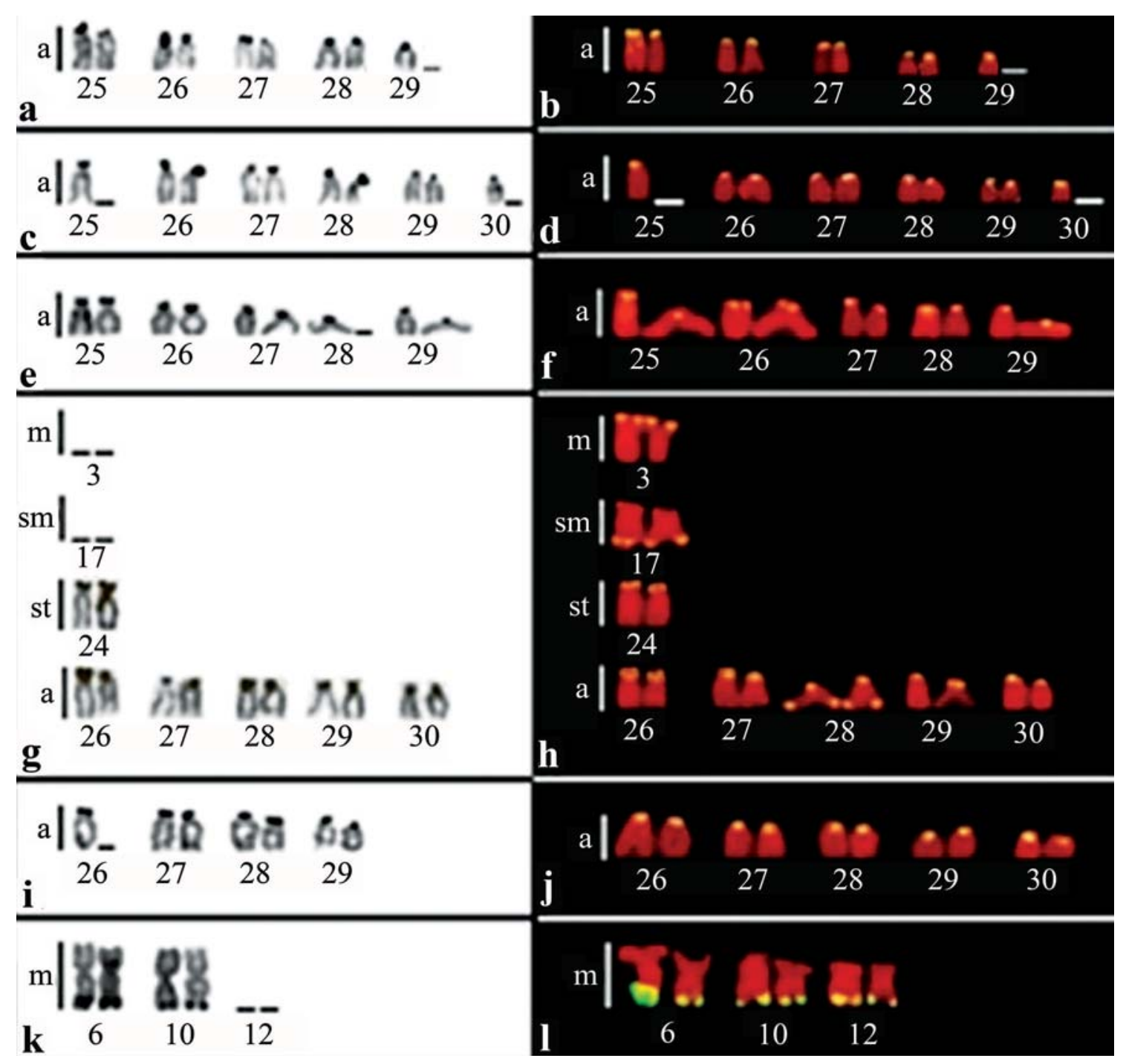

Fig. 2. Partial karyotypes of Serrasalmidae species showing Ag-NORs (left side) and 18S rDNA sites (right side): a-b) Serrasalmus elongatus; c-d) Serrasalmus maculatus; e-f) Serrasalmus cf. rhombeus; g-h) Serrasalmus rhombeus; i-j) Pygocentrus nattereri; k-l) Colossoma macropomum. Numbers indicate the corresponding chromosome pairs in the karyotypes of the species. 
Table 1. Karyotype characteristics in the studied species of Serrasalmidae. $2 \mathrm{n}=$ modal diploid number; $\mathrm{m}=$ metacentric, $\mathrm{sm}=$ submetacentric, $\mathrm{st}=$ subtelocentric, $\mathrm{a}=$ acrocentric chromosomes; $\mathrm{FN}=$ fundamental number; $\mathrm{p}=$ short $\mathrm{arm} ; \mathrm{q}=\mathrm{long}$ arm; $\mathrm{t}=$ terminal; Ag-NORs = nucleolar organizer regions stained with silver nitrate; $18 \mathrm{~S}$ rDNA = maximum number of sites detected by FISH; 5S rDNA = number of sites detected by FISH. *S. maculatus $=$ S. spilopleura cytotype A (according to Nakayama et al., 2000; Centofante et al., 2002a).

\begin{tabular}{|c|c|c|c|c|c|c|}
\hline Species & $2 n \mathrm{FN}$ & Karyotype formulae & Ag-NOR & $18 \mathrm{~S}$ rDNA & 5S rDNA & Reference \\
\hline S. altispinnis & 60110 & $24 m+20 s m+6 s t+10 a$ & $6-10 a, p, t$ & $10 \mathrm{a}, \mathrm{p}, \mathrm{t}$ & $2 \mathrm{~m}, 7^{\text {th }}$ pair & Nakayama et al. (2008) \\
\hline S. elongatus & 60108 & $22 \mathrm{~m}+22 \mathrm{sm}+4 \mathrm{st}+12 \mathrm{a}$ & $6-9 a, p, t$ & $9 \mathrm{a}, \mathrm{p}, \mathrm{t}$ & $2 \mathrm{~m}, 7^{\text {th }}$ pair & Present paper \\
\hline S. gouldingi & 60110 & $22 \mathrm{~m}+22 \mathrm{sm}+6 \mathrm{st}+10 \mathrm{a}$ & $5-8 \mathrm{a}, \mathrm{p}, \mathrm{t}$ & $6 \mathrm{a}, \mathrm{p}, \mathrm{t}+2 \mathrm{st}, \mathrm{p}, \mathrm{t}$ & $2 \mathrm{~m}, 7^{\text {th }}$ pair & Nakayama et al. (2008) \\
\hline *S. maculatus & 60108 & $24 m+20 s m+4 s t+12 a$ & $6-10 a, p, t$ & $10 \mathrm{a}, \mathrm{p}, \mathrm{t}$ & $2 \mathrm{~m}, 7^{\text {th }}$ pair & Present paper \\
\hline S. rhombeus & 60110 & $20 \mathrm{~m}+24 \mathrm{sm}+6 \mathrm{st}+10 \mathrm{a}$ & $5-10 a, p, t+2 s t, p, t$ & $10 \mathrm{a}, \mathrm{p}, \mathrm{t}+2 \mathrm{st}, \mathrm{p}, \mathrm{t}+2 \mathrm{sm}, \mathrm{q}, \mathrm{t}+2 \mathrm{~m}, \mathrm{p}, \mathrm{t}$ & $2 \mathrm{~m}, 7^{\text {th }}$ pair & Present paper \\
\hline S. cf. rhombeus & 58106 & $22 \mathrm{~m}+24 \mathrm{sm}+2 \mathrm{st}+10 \mathrm{a}$ & $5-9 \mathrm{a}, \mathrm{p}, \mathrm{t}$ & $10 \mathrm{a}, \mathrm{p}, \mathrm{t}$ & $2 \mathrm{~m}, 7^{\text {th }}$ pair & Present paper \\
\hline S. serrulatus & 60110 & $20 \mathrm{~m}+22 \mathrm{sm}+8 \mathrm{st}+10 \mathrm{a}$ & $4-12$ st-a, p, t & $8 \mathrm{a}, \mathrm{p}, \mathrm{t}+2 \mathrm{st}, \mathrm{p}, \mathrm{t}+1 \mathrm{~m}, \mathrm{q}, \mathrm{t}+1 \mathrm{~m}, \mathrm{p}, \mathrm{t}$ & $2 \mathrm{~m}, 7^{\text {th }}$ pair & Nakayama et al. (2008) \\
\hline P.nattereri & 60110 & $20 m+28 s m+2 s t+10 a$ & $5-7 \mathrm{a}, \mathrm{p}, \mathrm{t}$ & $10 \mathrm{a}, \mathrm{p}, \mathrm{t}$ & $2 \mathrm{~m}, 3^{\text {rd }}$ pair & Present paper \\
\hline C.macropomum & 54108 & $26 m+28 s m$ & $4 \mathrm{~m}-\mathrm{sm}, \mathrm{q}, \mathrm{t}$ & $6 \mathrm{~m}-\mathrm{sm}, \mathrm{q}, \mathrm{t}$ & $1 \mathrm{~m}, 12^{\text {th }}$ pair & Present paper \\
\hline
\end{tabular}

fluorescent in situ hybridization identifies ribosomal genes regardless of their activity status, whereas silver nitrate impregnation is only able to detect previously active sites (Miller et al., 1976). Therefore, some 18S rDNA sites that were undetectable by silver nitrate may correspond to inactive genomic regions. Secondly, NORs in Serrasalmidae are usually very small, probably due to a small number of gene copies, which does not allow its detection on the chromosomes. On the other hand, the occurrence of NOR transposition between different chromosomes, facilitated by transposable elements and the consequent diversity in their location within the karyotypes, cannot be excluded (Biémont \& Vieira, 2006).

In addition to the standard karyotypes with $2 \mathrm{n}=60$ chromosomes, previous reports in $S$. rhombeus described a cryptic form ( $S$. cf. rhombeus) bearing $2 \mathrm{n}=58$ chromosomes (Nakayama et al., 2001), as well as another karyomorph was identified by chromosomal and molecular analyses (Teixeira et al., 2006), suggesting that $S$. rhombeus is a complex of species.

This hypothesis is strengthened by the present data on 18 S rDNA sites, since $S$. cf. rhombeus and $S$. rhombeus differed in both number and localization of these sites on the chromosomes (Table 1, Fig. $2 \mathrm{f}$ and $\mathrm{h}$ ).

In general, the $5 \mathrm{~S}$ rDNA clusters are interstitially situated on the chromosomes of fish species, usually involving a single pair in the karyotype, which is thought to be a preferential condition for this group (Martins \& Wasko, 2004). Similarly, the 5S rDNA in all Serrasalmidae species was interstitially located on the long arms of a metacentric pair, without synteny with NORs. This chromosome corresponds to pair number 7 in Serrasalmus and probably pair number 3 in $P$. nattereri and pair number 12 in C. macropomum (Fig. 3).

A precise identification of the $5 \mathrm{~S}$ rDNA-bearing pair in the karyotypes of different species of Serrasalmidae was somewhat difficult to achieve without additional markers, since a great number of chromosomal pairs are morphologically similar. However, based on size, form, 5S rDNA location and conspicuous C-bands, these chromosomes were putatively homeologous between Serrasalmus and Pygocentrus (Fig. 3). Indeed, 5S rDNA-bearing chromosomes in all Serrasalmus species as well as in $P$. natterer $i$ had a peculiar C-positive band close to the centromere on the long arms, associated with the
5S rDNA genes. In some other Neotropical fish groups, such as Anostomidae, Parodontidae, and Prochilodontidae, 5S rDNA-bearing chromosomes also seem to be conserved (Martins \& Galetti Jr., 1999, 2000; Vicente et al., 2001; Centofante et al., 2002b; Jesus \& Moreira Filho, 2003; Hatanaka \& Galetti Jr., 2004). Meanwhile, the same inference is not valid for Serrasalmidae as a whole, once $5 \mathrm{~S}$ rDNA sites in $C$. macropomum were located on clearly different chromosomes when compared to the other studied species.

Based on inner anatomy, miological, and osteological characters, Machado-Allison (1983) subdivided Serrasalmidae into two distinct groups: "pacus" and "piranhas". Among "pacus", Colossoma is thought to represent one of the more derived genera. Among "piranhas", Catoprion is thought to be the most basal group, followed by Pygopristis, Pygocentrus, Pristobryconm, and Serrasalmus, the latter two corresponding to the more derived genera. On the other hand, molecular phylogeny based on mtDNA (Ortí et al., 1996) clustered "pacus" and "piranhas", and placed Colossoma as the basal genus for the family. Within this phylogenetic analysis, Catoprion remains the basal group of piranhas, along with Pristobrycon striolatus, followed by other species of Pristobrycon, Serrasalmus, and Pygocentrus.

All these species have a karyotype composed of m, sm, st, and a chromosomes, thus diverging from C. macropomum, which has $2 n=54 \mathrm{~m}$-sm chromosomes. The location of $5 \mathrm{~S} \mathrm{rDNA}$ sites in similar chromosomes also reinforces a closer relationship between Serrasalmus and Pygocentrus as well as the separation of Colossoma. Therefore, a number of karyotype traits corroborate the distance between Colossoma and other species of Serrasalmidae, as proposed by the phylogenetic hypotheses of Machado-Allison (1983) and Ortí et al. (1996). Moreover, the evident co-localization of 5S rDNA and C-bands on probable homeologous chromosomes supports the high proximity between the species of Serrasalmus and P. nattereri, as proposed by Ortí et al. (1996).

Considering C. macropomum as occupying the most basal position within Serrasalmidae, the karyotype differentiation observed in the other species would be derived from chromosome rearrangements, such as centric fissions, 


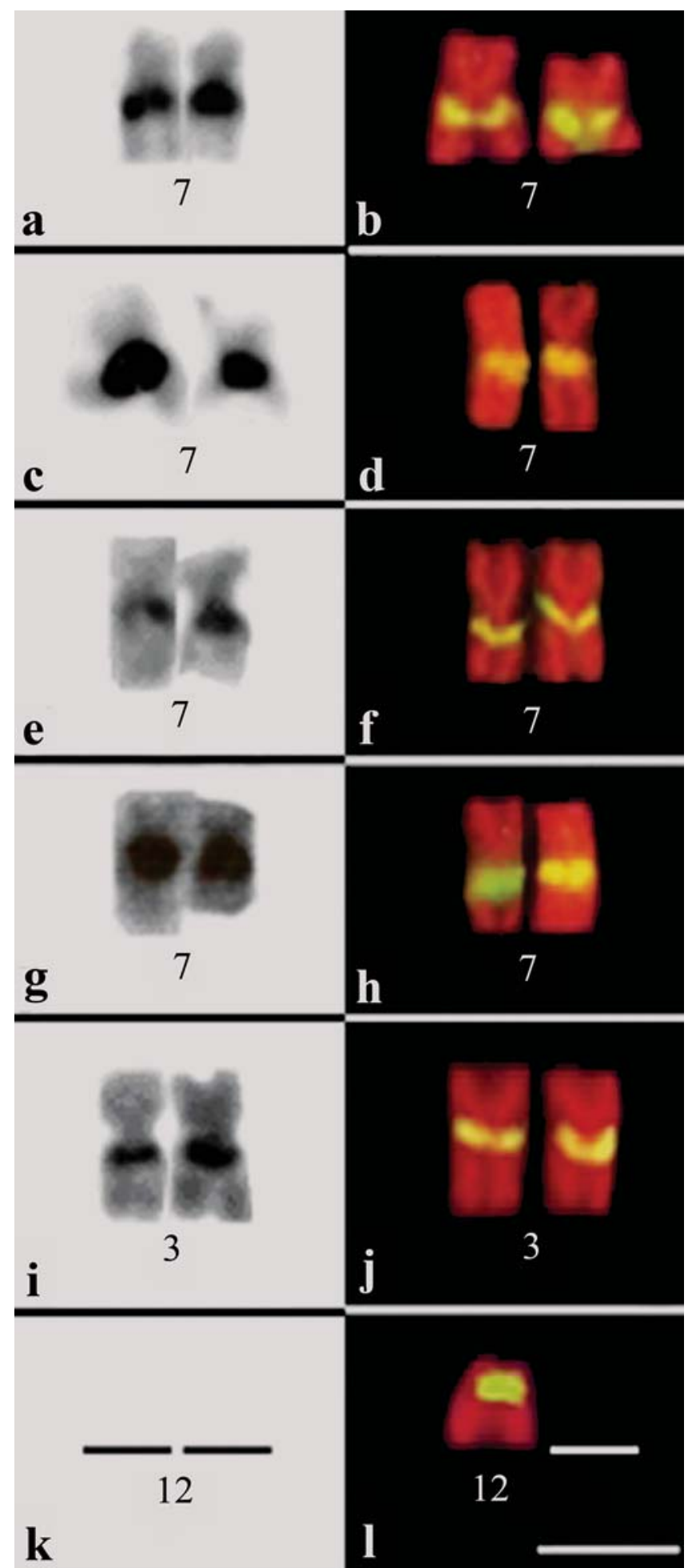

Fig. 3. Chromosome pairs of Serrasalmidae species showing the co-localization of the heterochromatic C-positive band (left side) and 5S rDNA site (right side): a-b) Serrasalmus elongatus; c-d) Serrasalmus maculatus; e-f) Serrasalmus cf. rhombeus; g-h) Serrasalmus rhombeus; i-j) Pygocentrus nattereri; k-I) Colossoma macropomum. Numbers indicate the corresponding chromosome pair in the karyotypes of the species. Pair 12 in Colossoma macropomum does not exhibit the conspicuous $\mathrm{C}$-band. increasing the basal diploid number from $2 \mathrm{n}=54$ metasubmetacentric chromosomes to $2 \mathrm{n}=58$ and 60 chromosomes, alongside with the formation of acrocentric chromosomes. Similarly, the NORs have also undergone numerical and positional modifications during the karyotype evolution of this fish group, changing from a location on m-sm chromosomes, as seen in C. macropomum, to a preferential location on st-a chromosomes, as observed in the other genera.

From this perspective, it is likely that the few m-sm chromosomes bearing $18 \mathrm{~S}$ rDNA, as detected in $S$. rhombeus and $S$. serrulatus, represent an ancestor feature similar to that found in C. macropomum. As for the $5 \mathrm{~S}$ rDNA clusters, their identical location in all Serrasalmus species and in $P$. nattereri suggests that, once established from a putative ancestor condition as that found in C. macropomum, their distribution remained conserved. However, while chromosomes bearing 5S rDNA sites are located in pair number 3 in $P$. natterer $i$ karyotype, they correspond to pair number 7 in Serrasalmus. Therefore, the same location of the $5 \mathrm{~S}$ rDNA sites on metacentric chromosomes and their co-localization with C-positive heterochromatin per se are not a unique feature of the genus Serrasalmus, since these aspects are also shared by $P$. nattereri. Instead, the exclusive characteristic of Serrasalmus must refer to the position of the chromosomes bearing such markers in the karyotype (pair number 7).

In conclusion, chromosome characteristics, particularly the analysis of ribosomal genes and C-bands, provided reliable cytotaxonomic markers for evaluating karyotype differentiation and evolutionary relationships among species of Serrasalmidae.

\section{Acknowledgements}

The authors would like to thank Jansen A. S. Zuanon for the specimens identification, Aldaléia C. dos Santos, and Marcelo de Bello Cioffi for assistance with the figures. This study was supported by the Instituto Nacional de Pesquisas da Amazônia (INPA): institution project PPI 2-3450; Conselho Nacional de Desenvolvimento Científico e Tecnológico CNPq/Programa de apoio a Núcleos de Excelência em Ciência e Tecnologia (PRONEX); Fundação de Amparo à Pesquisa do Estado do Amazonas - FAPEAM/Programa Integrado de Pesquisa e Inovação Tecnológica (PIPT); and IBAMA License \# 049/2004 and 006/2004. C.M. Nakayama was granted a doctoral fellowship from CNPq.

\section{Literature Cited}

Almeida-Toledo, L. F., F. Foresti, S. A. Toledo-Filho, G. Bernardino, W. Ferrari \& R. C. G. Alcantara. 1987. Cytogenetic studies in Colossoma macropomum, Colossoma mitrei and their interespecific hybrids. Selection, Hibridization and Genetic Engineering in Aquaculture (K Tiews, ed). Berlin, Heenemann Verlag, Pp. 190-195.

Bertollo, L. A. C., C. S. Takahashi \& O. Moreira Filho. 1978. Cytotaxonomic considerations on Hoplias lacerdae (Pisces, Erythrinidae). Brazilian Journal of Genetics, 1: 103-120. 
Biémont, C. \& C. Vieira. 2006. Junk DNA as an evolutionary force. Nature, 443: 521-524.

Centofante, L., J. I. R. Porto \& E. Feldberg. 2002a. Chromosomal polymorphism in Serrasalmus spilopleura Kner, 1858 (Characidae) from Central Amazon basin. Caryologia, 55: $37-$ 45 .

Centofante, L., L. A. C. Bertollo \& O. Moreira-Filho. 2002b. A ZZ/ ZW sex chromosome system in a new species of the genus Parodon (Pisces, Parodontidae). Caryologia, 55: 139-150.

Cestari, M. M. \& P. M. Galetti Jr. 1992a. Chromosome studies of Serrasalmus spilopleura (Characidae, Serrasalminae) from the Parana-Paraguay rivers: evolutionary and cytotaxonomic considerations. Copeia, 1992: 108-112.

Cestari, M. M. \& P. M. Galetti Jr. 1992b. Chromosome evolution in the genus Serrasalmus and citotaxonomic considerations about Serrasalminae (Characidae, Pisces). Brazilian Journal of Genetics, 15: 555-567.

Feldberg, E., J. I. R. Porto \& L. A. C. Bertollo. 1992. Karyotype evolution in Curimatidae (Teleostei, Characiformes) of the Amazon region. I. Studies on the genera Curimata, Psectrogaster, Steindachnerina and Curimatella. Brazilian Journal of Genetics, 15: 369-383.

Feldberg, E., J. I. R. Porto \& L. A. C. Bertollo. 2003. Chromosomal changes and adaptation of cichlid fishes during evolution. Pp. 285-308. In: Val, A. L. \& B. G. Kapoor (Eds.). Fish Adaptation. New Dehli \& New York: Science Publishers, INC, 432p.

Galetti Jr., P. M., F. Foresti, L. A. C. Bertollo \& O. Moreira-Filho. 1984. Characterization of eight species of Anostomidae (Characiformes) fish on the basis of the nucleolar organizer region. Caryologia, 37: 401-406.

Galetti Jr., P. M., E. B. Silva \& R. T. Cerminaro. 1985. Multiple NOR system in fish Serrasalmus spilopleura (Serrasalminae, Characidae). Brazilian Journal of Genetics, 8: 479-484.

Gaviria, J. I., M. Nirchio, A. Granado \& A. Estrada. 2005. Karyotype and nucleolar organizer regions of Pygocentrus caribe (Serrasalminae) from Caicara Del Orinoco, Venezuela. Interciencia, 30: 44-47.

Gold, J. R. 1984. Silver-staining and heteromorphism of chromosomal nucleolus organizer regions in North American cyprinid fishes. Copeia, 1984: 133-139.

Hatanaka, T. \& P. M. Galetti Jr. 2004. Mapping of the 18S and 5S ribosomal RNA genes in the fish Prochilodus argenteus Agassiz, 1829 (Characiformes, Prochilodontidae). Genetica, 122: 239-244.

Howell, W. M. \& D. A. Black. 1980. Controlled silver staining of nucleolus organizer regions with a protective colloidal developer: a 1-step method. Experientia, 3: 1014-1015.

Jesus, C. M. \& O. Moreira Filho. 2003. Chromosomal location of 5S and 18S rRNA genes in Prochilodus lineatus (Characiformes, Prochilodontidae). Caryologia, 56: 281-287.

Levan, A., K. Fredga \& A. A. Sandberg. 1964. Nomenclature for centromeric position on chromosomes. Hereditas, 52: 201-220.

Machado-Allison, A. 1983. Estudios sobre la sistemática de la subfamília Serrasalminae (Teleostei, Characidae). Parte II. Discussion sobre la condicion monofiletica de la subfamília. Acta Biologica Venezuelica, 11: 145-195.

Martins, C. \& P. M. Galetti Jr. 1999. Chromosomal localization of 5S rDNA genes in Leporinus fish (Anostomidae, Characiformes). Chromosome Research, 7: 363-367.

Martins, C. \& P. M. Galetti Jr. 2000. Conservative distribution of $5 \mathrm{~S}$ rDNA loci in Schizodon (Pisces, Anostomidae) chromosomes. Chromosome Research, 8: 353-355.
Martins, C. \& A. P. Wasko. 2004. Organization and evolution of 5S ribosomal DNA in the fish genome. Pp. 335-363. In: Williams, C. R. (Ed.). Focus Genome Research. New York: Nova Science Publishers, 424p.

Martins-Santos, I. C., H. F. Julio Jr. \& S. J. Santos. 1994. Chromosome study of two species of the genus Serrasalmus (Characidae, Serrasalminae) from the Paraná River. Caryologia, 59: 175-181.

Miller, D. A., V. G. Devi, R. Tantravahi \& O. J. Miller. 1976. Supression of human nucleolus organizer in mouse-human somatic hybrid cells. Experimental Cell Research, 101: 235-243.

Nakayama, C. M., M. Jégu, J. I. R. Porto \& E. Feldberg. 2001. Karyological evidence for a cryptic species of piranha within Serrasalmus rhombeus group (Characidae, Serrasalminae) in the Amazon. Copeia, 2001: 866-869.

Nakayama, C. M., J. I. R. Porto \& E. Feldberg. 2002. A comparative cytogenetic study of five piranhas species (Serrasalmus, Serrasalminae) from the Amazon basin. Genetica, 114: 231-236.

Nakayama, C. M., E. Feldberg \& L. A. C. Bertollo. 2008. Mapping of ribosomal genes and chromosomal markers in three piranha species of the genus Serrasalmus (Characidae, Serrasalminae) from the Amazon basin. Genetics and Molecular Biology, 31: 868-873.

Nirchio, M., A. S. Fenocchio, A. C. Swarça, J. E. Pérez, A. Granado \& A. Estrada. 2003. Cytogenetic characterization of hybrids offspring between Colossoma macropomum (Cuvier, 1818) and Piaractus brachypomus (Cuvier, 1817) from Caicara del Orinoco, Venezuela. Caryologia, 56: 405-411.

Oliveira, C., L. F. Almeida-Toledo, F. Foresti \& S. A. Toledo-Filho. 1988. Supernumerary chromosomes, Robertsonian rearrangement and multiple NORs in Corydoras aeneus (Pisces, Siluriformes, Callichthyidae). Caryologia, 41: 227-236.

Ortí, G., P. Petry, J. I. R. Porto, M. Jégu \& A. Meyer. 1996. Patterns of nucleotide change in mitochondrial ribosomal RNA genes and the phylogeny of piranhas. Journal of Molecular Evolution, 42: $169-182$.

Pendás, A. M., P. Morán, J. P. Freire \& E. García-Vázquez. 1994. Chromosomal mapping and nucleotide sequence of two tandem repeats of Atlantic salmon 5S rDNA. Cytogenetics and Cell Genetics, 67: 31-36.

Pinkel, D., T. Straume \& J. W. Gray. 1986. Cytogenetic analysis using quantitative, high sensitivity, fluorescence hybridization. Proceedings of the National Academy of Science, 83: 2934-2938.

Sumner, A. T. 1972. A simple technique for demonstrating centromeric heterochromatin. Experimental Cell Research, 75: 304-306.

Teixeira, A. S., C. M. Nakayama, J. I. R. Porto \& E. Feldberg. 2006. Esterase-D and chromosome patterns in Central Amazon piranha (Serrasalmus rhombeus Linnaeus, 1766) from Lake Catalão. Genetics and Molecular Biology, 29: 498-502.

Venere, P. C. \& P. M. Galetti Jr.1989. Chromosome evolution and phylogenetic relationships of some Neotropical Characiformes of the family Curimatidae. Brazilian Journal of Genetics, 12: 17-25.

Vicente, V. E., C. M. Jesus \& O. Moreira-Filho. 2001. Chromosomal localization of $5 \mathrm{~S}$ and $18 \mathrm{~S}$ rRNA genes in three Parodon species (Pisces, Parodontidae). Caryologia, 54: 365-369.

White, T. J., T. Bruns, S. Lee \& J. Taylor. 1990. Amplification and direct sequencing of fungal ribosomal RNA genes for phylogenetics. Pp. 315-322. In: Michael I., W. Thomas \& J. J. Sninsky (Eds.). PCR Protocols: a Guide to Methods and Applications. New York: Academic Press Inc, 432p.

Submitted December 7, 2010

Accepted November 29, 2011

Published March 30, 2012 